\title{
Pituitary LH levels and response to LH-RH in female rats pretreated with oestradiol
}

\author{
L. Debeljuk, V. Rettori and R. Rozados \\ Centro de Investigaciones en Reproducción, Facultad de Medicina, \\ Paraguay 2155 piso 10, Buenos Aires, Argentina
}

The pituitary response to LH-RH can be modified by sex steroids (Debeljuk, Arimura \& Schally, 1972a; Debeljuk, 1973; Debeljuk, Vilchez Martínez, Arimura \& Schally, 1974) which can affect the gonadotrophin stores in the pituitary gland (McCann \& Ramírez, 1964). It has been suggested, however, that an increased or decreased response to LH-RH is not necessarily correlated with an increase or decrease of pituitary gonadotrophin concentrations (Debeljuk, Arimura \& Schally, 1972b; Debeljuk, Rozados, Daskal \& Villegas Vélez, 1975). We therefore attempted to correlate changes in the pituitary response to LH-RH with pituitary LH concentrations in rats.

Female rats of the Wistar strain (mean weight $200 \mathrm{~g}$ ) were maintained on a diet of laboratory chow and vegetables, and had free access to water. The light schedule was $14 \mathrm{~h} \mathrm{light} / 24 \mathrm{~h}$. The stage of the oestrous cycle was checked every day by observation of the vaginal cytology for at least 3 cycles and only rats with regular 4-day cycles were selected. Intact rats on the first day of dioestrus were allocated to groups ( 12 rats/group) and were killed by decapitation, after treatment, on the 2nd day of dioestrus between 15.00 and $18.00 \mathrm{~h}, 20 \mathrm{~min}$ after i.v. injection of $0.2 \mathrm{ml}$ acidified saline (6 rats/group) or $400 \mathrm{ng}$ LH-RH (kindly supplied by Dr Andrew Schally, Tulane University School of Medicine, New Orleans, Louisiana) in $0.2 \mathrm{ml}$ acidified saline (6 rats/group). The animals in Group 1 were controls and received only $0.5 \mathrm{ml}$ corn oil s.c. The rats in Groups 2,3 and 4 received a s.c. injection of $20 \mu \mathrm{g}$ oestradiol benzoate (Sigma Chemical Company) in $0.5 \mathrm{ml}$ corn oil at 3,6 and $24 \mathrm{~h}$ respectively before the LH-RH injection. After ovariectomy 10 days previously, a further 48 rats (Groups 5, 6, 7 and 8 ) were treated as described above for intact rats.

At death, blood was collected from the trunk and serum was separated by centrifugation and kept frozen until assayed. Pituitaries were quickly extirpated and after removal of the neural lobe were weighed. Anterior pituitary tissue was kept frozen until homogenized in saline and assayed for LH by the double-antibody method described by Niswender, Midgley, Monroe \& Reichert (1968). An ovine LH preparation was used for labelling with ${ }^{125} \mathrm{I}$; the first antibody was an anti-ovine LH serum and NIAMDD-Rat LH-RP1 was used as the standard preparation.

The significance of the differences among groups was checked by means of Student's $t$ test and Duncan's new multiple range test (Steel \& Torrie, 1960).

\section{Results}

As shown in Table 1, serum LH levels were increased in the dioestrous and ovariectomized rats injected with LH-RH compared with those receiving saline only, although the magnitude of the response varied with the duration of oestradiol pretreatment. Pituitary LH concentration in the saline-injected intact animals $24 \mathrm{~h}$ after pretreatment with oestradiol benzoate (Group 4) was significantly lower $(P<0.05)$ than in the rats in the other two groups receiving saline and oestradiol (Groups 2 and 3). In the ovariectomized rats, pituitary LH concentrations in saline-injected rats were significantly different $(P<0.05)$ from those in LH-RH-injected rats only in the group treated with oestradiol benzoate for $24 \mathrm{~h}$ (Group 8 ).

From these results it is evident that the changes in the magnitude of the pituitary response to LH-RH that were seen from 3 to $24 \mathrm{~h}$ after the injection of oestradiol were not accompanied by concomitant changes in pituitary LH concentrations in intact dioestrous rats. This was also true for ovariectomized rats, except for those receiving oestradiol for $24 \mathrm{~h}$ : their response to LH-RH was maximal when the lowest pituitary LH concentration was noted. Although pituitary responsiveness 
Table 1. Mean \pm S.E.M. serum and pituitary $\mathrm{LH}$ concentrations in dioestrous or ovariectomized rats (6/group) after the injection of saline or $400 \mathrm{ng} \mathrm{LH}-\mathrm{RH}$ after pretreatment with oestradiol benzoate (OB) for various times

\begin{tabular}{|c|c|c|c|c|}
\hline & Corn oil & $\mathrm{OB}-3 \mathrm{~h}$ & OB-6 h & OB-24 h \\
\hline Dioestrous rats-Group & 1 & 2 & 3 & 4 \\
\hline $\begin{array}{l}\text { Serum LH }(\mathrm{ng} / \mathrm{ml}) \\
\text { Saline } \\
\text { LH-RH }\end{array}$ & $\begin{array}{c}8.98 \pm 2 \cdot 41 \\
292 \cdot 70 \pm 113 \cdot 53^{*}\end{array}$ & $\begin{array}{c}0.90 \pm 0.19 \dagger \\
17.66 \pm 3.02^{*} \dagger\end{array}$ & $\begin{array}{c}6 \cdot 90 \pm 1 \cdot 15 \\
80 \cdot 00 \pm 5 \cdot 45^{*} \dagger\end{array}$ & $\begin{array}{c}22 \cdot 25 \pm 7 \cdot 31 \dagger \\
1266 \cdot 60 \pm 214.36^{*} \dagger\end{array}$ \\
\hline $\begin{array}{l}\text { Pituitary LH }(\mu \mathrm{g} / \mathrm{mg}) \\
\text { Saline } \\
\text { LH-RH }\end{array}$ & $\begin{array}{l}7 \cdot 86 \pm 3.00 \\
9 \cdot 71 \pm 2 \cdot 85\end{array}$ & $\begin{array}{r}12.62 \pm 2.83 \\
5.59 \pm 1.38\end{array}$ & $\begin{array}{r}12 \cdot 37 \pm 2 \cdot 29 \\
5 \cdot 95 \pm 2 \cdot 19\end{array}$ & $\begin{array}{l}4 \cdot 13 \pm 1.05 \\
3.44 \pm 1 \cdot 18\end{array}$ \\
\hline Ovariectomized rats-Group & 5 & 6 & 7 & 8 \\
\hline $\begin{array}{l}\text { Serum LH }(\mathrm{ng} / \mathrm{ml}) \\
\text { Saline } \\
\text { LH-RH }\end{array}$ & $\begin{array}{c}392 \cdot 50 \pm 191 \cdot 81 \\
3013 \cdot 30 \pm 751 \cdot 42^{*}\end{array}$ & $\begin{array}{c}66 \cdot 91 \pm 13 \cdot 30 \dagger \\
186 \cdot 80 \pm 39 \cdot 47^{*} \dagger\end{array}$ & $\begin{array}{c}54 \cdot 00 \pm 7 \cdot 53 \dagger \\
477 \cdot 14 \pm 60 \cdot 91 * \dagger\end{array}$ & $\begin{array}{c}90.83 \pm 9.50 \dagger \\
4450.00 \pm 683.67^{*}\end{array}$ \\
\hline $\begin{array}{l}\text { Pituitary LH }(\mu \mathrm{g} / \mathrm{mg}) \\
\text { Saline } \\
\text { LH-RH }\end{array}$ & $\begin{array}{l}54 \cdot 57 \pm 8 \cdot 94 \\
50 \cdot 59 \pm 7 \cdot 88\end{array}$ & $\begin{array}{l}57 \cdot 22 \pm 4 \cdot 83 \\
56 \cdot 19 \pm 6 \cdot 85\end{array}$ & $\begin{array}{l}52 \cdot 17 \pm 5 \cdot 01 \\
44 \cdot 62 \pm 2 \cdot 91\end{array}$ & $\begin{array}{l}55 \cdot 24 \pm 2 \cdot 45 \\
40 \cdot 17 \pm 3 \cdot 10^{*}\end{array}$ \\
\hline
\end{tabular}

* Significantly different from value for respective saline-injected animals, $P<0.05$.

$\uparrow$ Significantly different from value for respective oil-injected animals, $P<0.05$.

to LH-RH can be modified by oestradiol it is evident that, at least under the conditions of the present experiment, the response, as determined by LH release, can be inhibited or augmented regardless of any apparent change in pituitary $\mathrm{LH}$ concentrations.

Previous reports have also suggested that an increment of the pituitary response to LH-RH may not be due simply to an increase in pituitary LH stores (Debeljuk et al., 1972b, 1975). A change, too subtle to be detected by the assay methods employed, in the pituitary content of a readily releasable pool of LH (Bogdanove \& Gay, 1967) could affect the pituitary response to LH-RH. Such a pool could constitute only a small part of the total pituitary LH content, a suggestion supported by findings of a lack of detectable pituitary LH depletion even after large doses of LH-RH (Debeljuk et al., 1972b). Evidence has also been produced for the existence of at least two pools of LH in the human pituitary, one responding quickly to LH-RH and the other requiring a more prolonged stimulation (Bremner \& Paulsen, 1974).

We thank Dr Niswender, Dr L. E. Reichert and NIAMDD, Bethesda, for gifts of the reagents used in the radioimmunoassays. This work was supported by a grant of the Consejo Nacional de Investigaciones Científicas y Técnicas, Argentina.

\section{References}

Bogdanove, E.M. \& Gay, V.L. (1967) Changes in pituitary levels of $\mathrm{LH}$ and FSH after cessation of chronic androgen treatment. Endocrinology 81, 930933.

Bremner, W.J. \& Paulsen, A.C. (1974) Two pools of luteinizing hormone in the human pituitary: evidence from constant administration of luteinizing hormone-releasing hormone. J. clin. Endocr. Metab. 39, 811-815.

DeBELJUK, L. (1973) Effect of gonadal steroids on the pituitary response to LH/FSH-RH. Acta physiol. latinoam. 23, 482-484.

Debeluuk, L., Arimura, A. \& Schally, A.V. (1972a) Effect of estradiol and progesterone on the $\mathrm{LH}$ release induced by $\mathrm{LH}-\mathrm{RH}$ in intact diestrous rats and anestrous ewes. Proc. Soc. exp. Biol. Med. 139, $774-777$.

Debeluuk, L., Arimura, A. \& Schally, A.V. (1972b) Studies on the pituitary responsiveness to LH-RH in intact male rats of different ages. Endocrinology 90, 585-588.

Debeljuk, L., Vilchez Martínez, J.A., Arimura, A. \& Schally, A.V. (1974) Effect of gonadal steroids on the response to LH-RH in intact and castrated male rats. Endocrinology 94, 15191524.

Debeluuk, L., Rozados, R., Daskal, H. \& Villegas VÉlez, C. (1975) Variation of the pituitary response 
to LH-RH during a 24-hr period in male, diestrous female and androgenized female rats. Neuroendocrinology 17, 48-53.

MCCANN, S.M. \& RamfRez, V.D. (1964). The neuroendocrine regulation of hypophyseal luteinizing hormone secretion. Recent Prog. Horm. Res. 64, 131170.
Niswendiki, G.D., Midgley, A.R., Monrob, S.E. \& ReICHERT, L.E. (1968) Radioimmunoassay for rat luteinizing hormone with an anti-ovine LH serum and ovine LH ( ${ }^{131}$ ). Proc. Soc. exp. Biol. Med. 136, 1115-1118.

Straz, R.G.D. \& ToRRIE, J.H. (1960) Principles and Procedures of Statistics. McGraw-Hill, New York.

Received 22 Decenber 1976 